\title{
Relationship between Health Educators' Variables and Retention in Public Secondary Schools in Delta and Edo States
}

\author{
Okudaye, I.N: College of Education, Agbor, Delta State, Indonesia.
}

\begin{abstract}
This study was undertaken to investigate relationship between health educators' variables and job retention in public secondary schools in Delta and Edo states. The study employed correlational design. The population was 1122 principals and health educators' in public secondary schools in Delta and Edo States. The population includes 469 principals and 215 health educators 'in public secondary schools in Delta State and 259 principals and 179 health educators 'in public secondary schools in Edo State. The researcher sampled 364 (50\%) principals and the entire 394 health educators' in public secondary schools in Delta and Edo States. The stratified random sampling technique was utilised to choose $50 \%$ of principals in the two states that were used in the study. The instrument for the study was a questionnaire titled Health Educators' Variables and Retention in Public Secondary Schools Questionnaire (HEVRPSSQ). Pearson Product Moment Correlational Coefficient ( $r$ ) was used to establish the reliability of the questionnaire. Overall coefficient of the whole test value of Pearson Product Moment Correlational Coefficient ( $r$ ) was 0.79 . Items on the questionnaire were scored by means of the four points scoring scale of Strongly Agree (4 points), Agree (3 points), Disagree (2 points) and Strongly Disagree (1 point). Out of the entire copies of $746 q u e s t i o n n a i r e s$ administered, 1,197 copies were retrieved. Principals were 359 and health educators' were 387. Mean rating and standard deviation were utilised to answer the three research questions. Pearson Product Moment Correlational Coefficient ( $r$ ) was utilised to test the three null hypotheses formulated to guide the study at 0.05 levels of significance. Findings showed that work load, class sise with health educators' retention negatively in public secondary schools in Delta and Edo States. Supportive principals with health educators' retention positively in public secondary schools in Delta and Edo States. There was a significant relationship among work load, class size, supportive principals and job retention in public secondary schools in Delta and Edo States. It was concluded in the study that work load, class size negatively relate with health educators 'retention in public secondary schools in Delta and Edo States was low as the ratings were low. Supportive principals negatively relate with health educators' retention in public secondary schools in Delta and Edo States was high as the ratings were high. It was recommended in the study that work load should be organised for health educators in public secondary schools in Delta and Edo States to enhance their' retention, class size should be well stated to enhance health educators' retention in public secondary schools in Delta and Edo States and competent mentors should be used in work load plans for health educators to enhance their retention in teaching in public secondary schools in Delta and Edo States.
\end{abstract}

Key words: Delta and Edo states, Health educators' Public secondary schools, Relationship, Retention, Teaching variables.

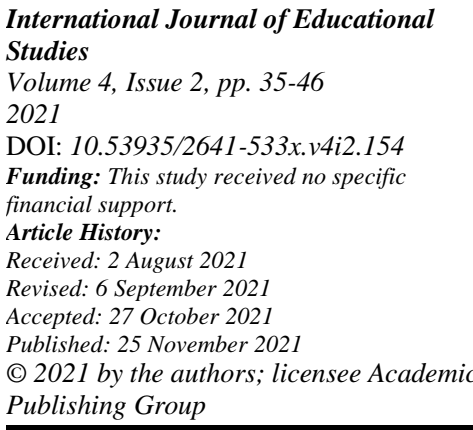

\section{Introduction}

The issue of how teacher job relate with the learning progression is one of the major persuasive and significant feature of the job. Realizing how schools can fashion quality learning setting and how students can effectively learn is not an easy job. Through health educators who are contented in teaching, students are akin to study and have the understanding of scholarship. In an inquiry, Certo and Fox (2002) acknowledged that 
job setting significantly relate with health educators ' job contentment and retention. In an examination, $\mathrm{Ng}$ and Peter (2010) signified that teacher retention cannot be linked to one issue, as a range of job and special issues influence a teacher's choice to depart teaching.

In an inquiry, Henry, Bastian, and Fortner (2011) found that health educators' who choose to depart teaching are fewer efficient than those who stay, which not merely influence those they perform with excluding students academic performance. In an investigation, Perrachione, Rosser, and Petersen (2008) accepted that unworkable prospect positioned on them by principal's influence them negatively to remain in teaching. In an investigation, Jerome (2013) established that if schools centers on achieving the requirements of their health educators, the health educators will endeavor to perform effectively in teaching. In an inquisition, National Professional Health educators " Organisation of South Africa (2002) revealed that poor administrative approaches, lack of support expected, incessant alteration in method, guiding principle, inadequate salary, inadequate communication, large class sise, inadequate educational assets, sum of power to take own plan, and inadequate promotion projection as factors influencing health educators ' job commitment.

In an investigation, Hughes (2012) recognised that health educators often prefer to use their teaching job with students as they have an inherent wish to assist students. In an inquiry, Gardner (2010) established that large class sises with more than usual intensity of students with particular requirements guide health educators to account increased height of job frustration. In an investigation, Craig (2014) ascertained that some health educators determined to depart teaching job due to reluctant to obey hard burden positioned on them. In an inquest, Greenlee and Brown (2009) repeated a call for a helpful setting to be made possible by principals, not one that is discordant and humiliating. In an investigation, Anhorn (2008) documented that $20 \%$ to $30 \%$ of health educators depart Teaching job in the initial five years, with most fresh health educators who depart, did so in the initial 2 years. He further found that complex job, imprecise anticipations, insufficient assets, loneliness, job conflict and certainty distress are some major motives for leaving

In an inquest, Sutcher, Darling-Hammond, and Carver-Thomas (2016) found that job displeasure, mainly concerning to physical setting, school administration and guiding principle were the primary motives why health educators willingly leave teaching job. In an investigation, Mee and Haverback (2014) found that administrative support, classroom administration, freedom, salary, students' inspiration, rules and regulations, teacher training and pre-service occurrence, set of courses, form of school setting and experience height relate with health educators ' retention. In an investigation, Sass, Seal, and Martin (2010) established that principals have a significant influence on health educators and school climate commence with them.

In an examination, Greenlee and Brown (2009) discovered that health educators are further probable to stay in teaching job in elevated need schools if principals offer a constructive school climate. They further found that principals of efficiently structuring the capabilities of health educators to develop students' performance were low. In an investigation, Sass et al. (2010) recognised that there was significant relationship between instructional support and health educators' job frustration. They further found that health educators with lesser anxiety height are prone to not just be more efficient in teaching but as well boost students' scholarship.

In an inquisition, Margolis (2008) found that certain clusters of health educators who are at a turning point in teaching are greatly prejudiced by the sustenance or short of it from their principals. In an inquisition, Gonzalez, Brown, and Slate (2008) instituted that when principals showed them disregard, choosing to bring health educators downward instead of supporting them. This disregard was frequently performed before. They further found that principals "deserted" difficult students in the classrooms, fashioning unwanted learning setting for both health educators and additional students. In an investigation, Petty, Fitchett, and O'Connor (2012) established that health educators were aggravated to carry on teaching in a high-need schools for the reason that they are concerned about them, had well-built administrative support, and a constructive school setting.

In an inquisition, Johnson and Birkeland (2003) ascertained that health educators who deemed triumphant with students and whose schools were prearranged to support them in their teaching... were more likely to stay in their schools, and in teaching, than health educators whose schools were not well prearranged. In an inquisition, Supovitz, Sirinides, and May (2010) discovered that principals influence students' learning ultimately by persuading how health educators utilise instructional practices in the teaching. In an inquiry, Wahlstrom and Louis (2008) found that though school enhancement and students; academic performance is

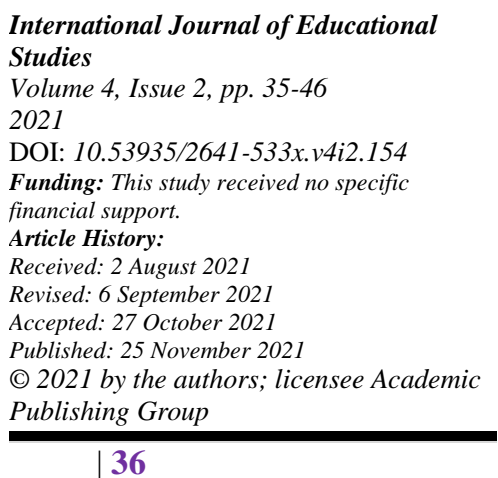


influenced by faith between the principals and health educators, it wasn't as significant as formerly supposed. Ogboro and Adeyemi (2017) noted that teacher deployment is decided by the job of work-load which is the instruction hours per week for health educators. Anywhere the employment is out of order; it could outcome in including a number of health educators with more work-load than others. In an inquiry, Ibadin (2010) found that health educators in urban secondary schools in 2008/2009 academic year were underused

\subsection{State of the Problem}

Understanding professional satisfaction and retention is among the keys to school improvement. Some health educators leave to take on other education-related jobs, including those that provide them with a source of upward mobility. Additionally, some leave the teaching profession or move to another school for personal reasons. Most health educators left the teaching profession for similar reasons, including job dissatisfaction as they desired better jobs, better careers, and other opportunities outside of education. Salary issues, lack of administrative support, and student motivation issues also influence exit attrition. Positioning of health educators in public secondary schools in Delta and Edo states, had been unbalanced

\subsection{Research Questions}

To guide study, the following research questions were raised:

1. What is the relationship between work load and retention in public secondary schools in Delta and Edo states?

2. What is the relationship between class size and retention in public secondary schools in Delta and Edo states?

What is the relationship between supportive principals and retention in public secondary schools in Delta and Edo states?

\subsection{Hypotheses}

The following null hypotheses were formulated to guide the study:

1. There is no significant relationship between work load and retention in public secondary schools in Delta and Edo states.

2. There is no significant relationship between class size and retention in public secondary schools in Delta and Edo states.

3. There is no significant relationship between supportive principals and retention in public secondary schools in Delta and Edo states.

\subsection{Purpose of the Study}

This study investigated relationship between work load and retention in public secondary schools in Delta and Edo states. Particularly the study investigated:

1. The relationship between work load and retention in public secondary schools in Delta and Edo states.

2. The relationship between class size and retention in public secondary schools in Delta and Edo states.

3. The relationship between supportive principals and retention in public secondary schools in Delta and Edo states.

\section{Theoretical Framework: The Theory of Education Production Function of Coleman, (1966).}

The theoretical framework used in this study was the concept of Education Production (Coleman, 1966). This theory recount to different schools' contribution influence health educators ' retention and students' learning in the schools. The theoretical thought of Coleman (1966) was that different school contribution such as work load, facilities, class size, administrative support, students, quality of teaching, influence health educators ' retention and students' academic performance in schools. The concept of Education Production Function recount with the efficient use of the health educators in the schools to enhanced internal competence of the schools and scholarship result of the students. The significance of the theoretical framework of the Education Production Function on teacher use is based on the organised level of use of health educators to meet the requisite of every subject taught in the schools, ensuring class size and supportive principals

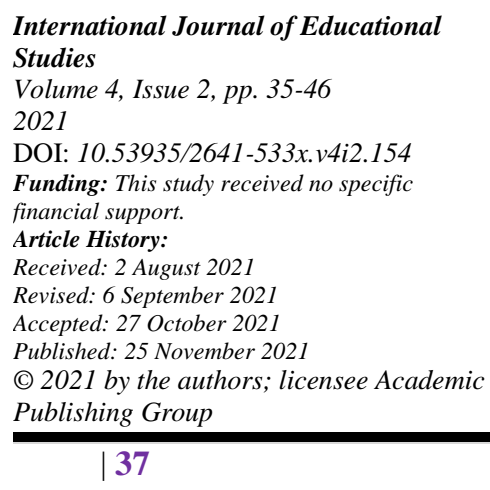


Manpower Exploitation Theory of Dyer and Reeves (1995). Manpower exploitation theory advocated by Dyer and Reeves (1995) was as well used in the study. They based the theory on the magnitude and excellence of manpower. Their thought is that the elevated the amount of labour based on performance, which comprises labour force, involvement and daily job hours; the elevated the level of performance. The aspects of the theory were on the amount of job hours that could characterise job performance.

\section{Relationship between Work Load and Retention in Public Secondary Schools in Delta and Edo States}

The school performs with principals, who describes and allocates jobs to health educators in terms of their areas of competency. Positioning of health educators in secondary schools entails the allocation of work-load. The work load advancement in appraising the tempo of allocation decode to teaching time of subjects to be taught daily and weekly. The suggested time per subject based on the guiding principle on least normal as stated in the Federal Republic of Nigeria (2014) in her National Policy on Education is a least of 18 periods and a highest of 24 periods weekly for every teacher. In an investigation, World Bank: Global Education Centre (2005) found that major African nations were confronted with the dilemma of exploitation of health educators in secondary schools. In an inquest, Smithers and Robinson (2000) instituted that there was an uneven allotment of health educators with deficiency in a number of subject areas while a number of have overload. Several health educators are extremely utilised while others were inadequately utilised.

One of the major variables shaping the provision and need for health educators in secondary schools are the adequate use of health educators. Health educators' use is shape by the allocation of work-load which is instruction hours weekly for health educators . A further determinant is the class sise which is teacher- student ratio. The third issue is the administration of health educators. This recount to the administrative job of the principals (World Bank: Global Education Centre, 2005). In their different inquiries, Higton et al. (2017) and Sellen (2016) confirmed that whereas number of hours job and rate of marking and criticism are not related with health educators ' retention. In an investigation, Ogboro and Adeyemi (2017) found that there was inadequate positioning and irregular allotment of graduate health educators to public schools in Edo State. In addition, poor use of these health educators was very clear. Consequently, the investigation ended that job performance would be very little.

In an inquest, Moritz (2011) instituted that there was a significant relationship between workload and retention. In an inquisition, revealed that crossbreed health educators would normally have a abridged teaching workload in-contrast to a conventional health educators and would complete non-teaching jobs in the remaining part of their years in teaching. In an investigation, Craig (2014) ascertained that some health educators determined to depart teaching job due to reluctant to obey hard burden positioned on them. In an investigation, Anhorn (2008) documented that $20 \%$ to $30 \%$ of health educators depart teaching job in the initial five years, with most fresh health educators who depart, did so in the initial 2 years. He further found that complex job, imprecise anticipations, insufficient assets, loneliness, job conflict and certainty distress are some major motives for leaving. In an examination, found that some health educators were extremely used in their subject region as well to non scholastic jobs. The examination acknowledged about 27 diverse nonscholastic jobs that added to the assigned job of instruction eras. Such non- scholastic jobs comprises class activities , morning congregation, social actions such as cultural dances, inter house sports, agriculture, hygiene, organizing class time table, students' control etc. In an inquiry, Bennell (2004) found that a number of health educators were extremely used. The inquiry affirmed that the widespread rationales for low teaching load were small size schools, overloaded set of courses, inadequate classroom and a prevalence of sole subject health educators. In a study, Enogholase (2013) established that not lesser than 3,000 health educators were sacked in teaching devoid of arrangement to employ new health educators and when the schools were critically short-staffed. In an inquisition, recognised that teacher's job performance and retention rely on the sum of endeavor they assign to teaching and their outcomes are decided by their skills, personality and job awareness.

Relationship between Class Size and Retention in Public Secondary Schools in Delta and Edo States. The number of diverse classes allocated daily is a better decisive factor for shaping teaching load than the actual number of hours spent teaching. Class size should be similar to other subjects but with differences where needed. In an inquisition, Johnson and Birkeland (2003) ascertained that health educators who deemed triumphant with students and whose schools were prearranged to support them in their teaching were more likely to stay in teaching job, than health educators whose schools were not well prearranged in spite of class

International Journal of Educational
Studies
Volume 4, Issue 2, pp. $35-46$
2021
DOI: $10.53935 / 2641-533 x . v 4 i 2.154$
Funding: This study received no specific
financial support.
Article History:
Received: 2 August 2021
Revised: 6 September 2021
Accepted: 27 October 2021
Published: 25 November 2021
() 2021 by the authors; licensee Academic
Publishing Group
Publishing Group 
size. In an exploration, instituted that inadequate inspiration and support of health educators, inadequate commitment by health educators, inadequate health educators, large class size, inadequate position of teaching, inadequate learning setting, inadequate student study habits, inadequate approaches to learning, altering worth of the society, unproductive supervision by principals were issues contributing to the turndown in health educators' retention.

Relationship between Supportive Principals and Retention in Public Secondary Schools in Delta and Edo states.

Supportive Principals is the extent to which health educators believe that their principals worth their involvement and be concerned about their welfare (Rhoades \& Eisenberger, 2002). In an investigation, Spector (2016) established that supportive principals fashion a lesser turnover plan. In a study, Demerouti, Bakker, Nachreiner, and Schaufeli (2001) established that supportive principals encourage health educators' readiness to perform job in a longer period of time. In an exploration, Mathieu and Zajac (1990) recognised that supportive principals encourage teacher's commitment to them.

In an inquiry, instituted that there was a positive relationship between supportive principals and retention of health educators. In an analysis, Eisenberger, Huntington, Hutchison, and Sowa (1986) ascertained that health educators swap obligation to the principals for better concern and support from the principals. In an inquisition, Kersaint, Lewis, Potter, and Meisels (2007) discovered that health educators recognise inadequate principals' support among them. In an examination, Hawkins (2018) found that there was a positive relationship between supportive principals and health educators' retention and commitment. Principal's job are to organise, direct and sustain teaching by classifying goals, appraising performance, providing organizational resources, building a supportive emotional climate (Sergiovanni, McCarthy, \& Kelleher, 2004). In a study, study quoted in Pekins (2016) found that school setting was made up of association, which comprises involvement, relationship with others and health educators' support.

In a search, Bennell (2004) observed that there was significant relationship between hours of work, huge class sises, more subjects, constantly altering set of courses and health educators ' retention. In an inquest, Sutcher et al. (2016) found that job dissatisfaction, particularly concerning to physical setting, school administration and guiding principle were the primary motives why health educators willingly leave teaching job.

In an inquest, that created numerous strong opinions sustaining the significant administrative job that principals perform schools and revealed that in order for schools to thrive they must perform successfully. In an investigation, Mee and Haverback (2014) found that administrative support, classroom administration, freedom, salary students' inspiration, rules and regulations, teacher training and pre- service occurrence, set of courses, form of school setting and experience height relate with health educators' retention. In an investigation, Sass et al. (2010) established that principals have a significant influence on health educators and school climate commence with them. In an inquisition, Supovitz et al. (2010) discovered that principals influence students' learning ultimately by persuading how health educators utilise instructional practices in the teaching. In an inquest, Wahlstrom and Louis (2008) ascertained that though school enhancement and students; academic performance is influenced by faith between the principals and health educators, it wasn't as significant as formerly supposed. In an inquisition, established that there was significant relationship between Supportive Principalsand health educators' persist in teaching.

In an examination, Greenlee and Brown (2009) discovered that health educators are further probable to stay in teaching job in elevated need schools if principals offer a constructive school climate. They further found that that principal efficiently structuring the capabilities of health educators to develop students' performance was low. In an investigation, Sass et al. (2010) recognised that there was significant relationship between instructional support and health educators' job frustration. They further found that health educators with lesser anxiety height are prone to not just be more efficient in teaching but as well boost students' scholarship. In an inquisition, Margolis (2008) found that certain clusters of health educators who are at a turning point in teaching are greatly prejudiced by the sustenance or short of it from their principals. In an inquisition, Gonzalez et al. (2008) instituted that when principals showed them disregard, choosing to bring health educators downward instead of supporting them. This disregard was frequently performed before. They further found that principals "deserted" difficult students in the classrooms, fashioning unwanted learning setting for both health educators and additional students. In an investigation, Petty et al. (2012) established

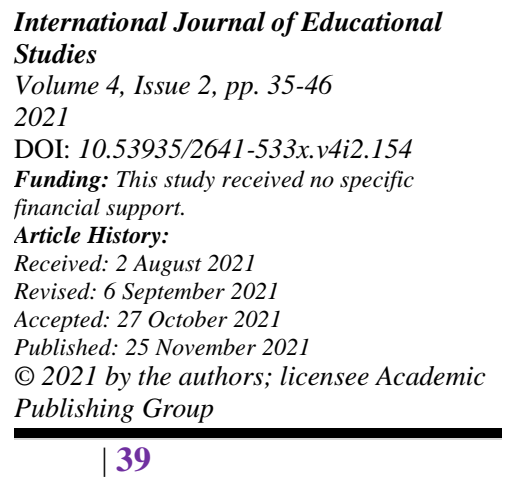


that health educators were aggravated to carry on teaching in a high-need schools for the reason that they are concerned about them, had well-built administrative support, and a constructive school setting.

In a search, found that no health educators had concern in parting the teaching to become principals due to augmented answerability. In an examination, established that health educators perform their job in separately which hampers their capacity to perform jointly and be trained by others. In an inquiry, Petty et al. (2012) established monetary additional benefits would attract health educators in school administration. In an inquest, Greenlee and Brown (2009) repeated a call for a helpful setting to be made possible by principals, not one that is discordant and humiliating. In an inquiry, found that though teacher relocation may not emerge to influence teacher's endeavors, it might influence the schools' which in sequence influence health educators ' recruitment.

\section{Method}

The study employed correlational design. The population was 1122 principals and health educators' in public secondary schools in Delta and Edo States. The population includes 469 principals and 215 health educators ' in public secondary schools in Delta State and 259 principals and 179 health educators ' in public secondary schools in Edo State. The researcher sampled 364 (50\%) principals and the entire 394 health educators' in public secondary schools in Delta and Edo States. The stratified random sampling technique was utilised to choose $50 \%$ of principals in the two states that were used in the study. The instrument for the study was a questionnaire titled Health Educators' Variables and Retention in Public Secondary Schools Questionnaire (HEVRPSSQ). To guarantee the internal constancy of the questionnaire, the researcher used split-half procedure to test the reliability of the instrument with piloting. 40 principals and 40 health educators ' in Delta state and 40 principals and 40 health educators ' in Edo state The researcher administered the instrument to principals and health educators' in public secondary schools in Delta and Edo States that were not integrated into the study. Pearson Product Moment Correlational Coefficient (r) was used to establish the reliability of the questionnaire. The value of Pearson Product Moment Correlational Coefficient (r) for work load 0.77. The value of Pearson Product Moment Correlational Coefficient (r) for class size was 0.81 and Pearson Product Moment Correlational Coefficient (r) for supportive principals was 0.79 . Overall coefficient of the whole test value of Pearson Product Moment Correlational Coefficient (r) was 0.79 . Items on the questionnaire were scored by means of the four points scoring scale of Strongly Agree (4 points), Agree (3 points), Disagree (2 points) and Strongly Disagree (1 point). Out of the entire copies of 746questionnaires administered, 1,197 copies were retrieved. Principals were 359 and health educators' were 387 . Mean rating and standard deviation were utilised to answer the three research questions. Mean rating of 2.50 was taken as the critical level of receipt, at the same time mean rating below 2.50 was rejected. Pearson Product Moment Correlational Coefficient (r) was utilised to test the three null hypotheses formulated to guide the study at 0.05 levels of significance.

\subsection{Presentation of Results}

Research Question 1.

What is the relationship between work load and health educators' retention in public secondary schools in Delta and Edo states?

The data in Table 1 shows that the Mean rating from items 1 to 10 on relationship between work load and health educators' retention in public secondary schools in Delta and Edo States. The respondents agreed on items 1 only that they learnt from novice health educators.

With the data in Table 1 and the mean rating from items 1 to 10 , the subsequent were noted. The mean rating for Principals was 2.11 and standard deviation of 0.25 while the mean rating for Health educators was 2.46 and standard deviation of 0.91 . Utilizing the level of acceptance for the study as 2.50 , the ratings of principals and health educators were lower than the criterion level of acceptance. This showed that there was norelationship between work load and health educators' retention in public secondary schools in Delta and Edo States was low as the ratings were low.

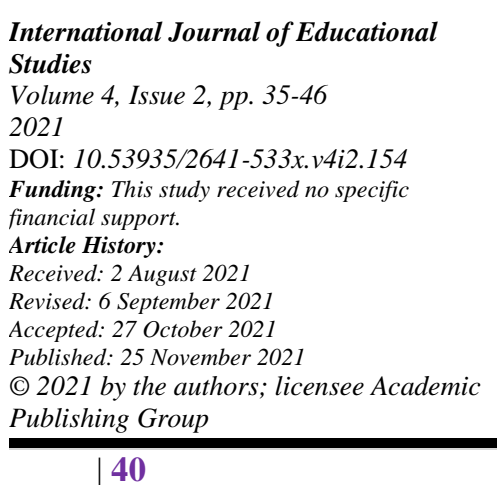


Table-1. Mean Rating of Respondents on Relationship between Work load and Health Educators' Retention in Public Secondary Schools in Delta and Edo States.

\begin{tabular}{|c|c|c|c|c|c|c|c|c|c|}
\hline \multirow{2}{*}{$\mathbf{S} / \mathbf{N}$} & \multirow{2}{*}{$\begin{array}{l}\text { Relationship between Work load and } \\
\text { Health educators, Retention in } \\
\text { Public Secondary Schools in Delta } \\
\text { and Edo states. }\end{array}$} & \multicolumn{3}{|c|}{ Principals } & \multicolumn{5}{|c|}{ Health educators } \\
\hline & & $\mathbf{N}$ & $\overline{\mathbf{X}}$ & SD & Decision & $\mathbf{N}$ & $\overline{\mathbf{X}}$ & SD & Decision \\
\hline 1. & $\begin{array}{l}\text { The principal allocate } 24 \text { periods } \\
\text { weekly } \\
\text { to some health educators }\end{array}$ & 359 & 3.49 & 0.71 & + & 387 & 3.93 & 0.87 & + \\
\hline 2. & $\begin{array}{l}\text { The principal allocate } 30 \text { periods } \\
\text { weekly to } \\
\text { some health educators }\end{array}$ & 359 & 2.47 & 1.21 & - & 387 & 2.43 & 1.12 & - \\
\hline 3. & $\begin{array}{l}\text { The principal highly utilised some } \\
\text { health educators in their teaching } \\
\text { subject areas. }\end{array}$ & 359 & 2.41 & 1.09 & - & 387 & 2.40 & 0.81 & - \\
\hline 4. & $\begin{array}{l}\text { The principal involve health educators } \\
\text { in } \\
\text { classroom administration }\end{array}$ & 359 & 2.39 & 1.17 & - & 387 & 2.37 & 1.03 & - \\
\hline 5. & $\begin{array}{l}\text { The principal involve health educators } \\
\text { in } \\
\text { opening assembly, }\end{array}$ & 359 & 2.37 & 1.05 & - & 387 & 2.33 & 0.77 & - \\
\hline 6 & $\begin{array}{l}\text { The principal involve health educators } \\
\text { in } \\
\text { social activities }\end{array}$ & 359 & 2.35 & 0.83 & - & 387 & 2.31 & 1.09 & - \\
\hline 7 & $\begin{array}{l}\text { The principal over use health educators } \\
\text { due to school size }\end{array}$ & 359 & 2.33 & 0.93 & - & 387 & 2.25 & 1.05 & - \\
\hline 8 & $\begin{array}{l}\text { The principal over use health educators } \\
\text { due to overcrowded curricula }\end{array}$ & 359 & 2.29 & 0.95 & - & 387 & 2.24 & 0.85 & - \\
\hline 9 & $\begin{array}{l}\text { The principal over use health educators } \\
\text { due to insufficient classroom. }\end{array}$ & 359 & 2.25 & 0.77 & - & 387 & 2.19 & 0.79 & - \\
\hline 10 & $\begin{array}{l}\text { The principal over use health educators } \\
\text { due to a predominance of single subject } \\
\text { health educators }\end{array}$ & 359 & 2.25 & 0.77 & - & 387 & 2.13 & 0.75 & - \\
\hline & Total & & 21.1 & 2.49 & & & $24.5 \varepsilon$ & 9.13 & \\
\hline & Grand Mean & & 2.11 & 0.25 & & & 2.46 & 0.91 & \\
\hline
\end{tabular}

Research Question 2: What is the relationship between class size and health educators' retention in public secondary schools in Delta and Edo states?

The data in Table 2 shows that the mean rating from items 1 to 6 on relationship between class size and health educators' retention in public secondary schools in Delta and Edo States. The respondents disagreed on all the items. With the data in Table 2 and the mean rating from items 1 to 6 , the subsequent were noted. The mean rating for principals was 2.47 and standard deviation of 0.97 while the mean rating for health educators was 2.42 and standard deviation of 0.96 . With the level of acceptance for the study as 2.50 , the ratings of principals and health educators were lower than the criterion level of acceptance. This showed there was no relationship between class size and health educators' retention in public secondary schools in Delta and Edo States was low as the ratings were low.

Studies

Volume 4, Issue 2, pp. 35-46

2021

DOI: $10.53935 / 2641-533 x . v 4 i 2.154$

Funding: This study received no specific

financial support.

Article History:

Received: 2 August 2021

Accepted: 27 October 2021

Published: 25 November 2021

(C) 2021 by the authors; licensee Academic

Publishing Group 
Table-2. Mean Rating of Respondents Relationship between Class Size and Health Educators ' Retention in Public Secondary Schools in Delta and Edo states.

\begin{tabular}{|c|c|c|c|c|c|c|c|c|c|}
\hline \multirow{3}{*}{$\begin{array}{l}\mathbf{S} / \\
\mathbf{N}\end{array}$} & \multirow{2}{*}{\multicolumn{2}{|c|}{$\begin{array}{l}\text { Relationship between Class Size and } \\
\text { Health Educators' Retention in } \\
\text { Public Secondary Schools in Delta N }\end{array}$}} & \multicolumn{4}{|c|}{ Principals } & \multicolumn{3}{|c|}{ Health educators } \\
\hline & & & & & & & & & \\
\hline & $\begin{array}{l}\text { Public Secondary Schools in Delta } 1 \\
\text { and Edo } \\
\text { states. }\end{array}$ & & $\mathbf{X}$ & SD & Decision $\mathrm{Y}$ & & $x^{-}$ & SD & Decision \\
\hline 1. & $\begin{array}{l}\text { The principal ensures that class size is } \\
\text { uniform in all classes. }\end{array}$ & 359 & 2.87 & 1.09 & + & 387 & 2.95 & 0.77 & + \\
\hline 2. & $\begin{array}{l}\text { The principal ensures that there are } 40 \\
\text { students per class. }\end{array}$ & 359 & 2.47 & 0.81 & - & 387 & 2.45 & 1.13 & - \\
\hline 3. & $\begin{array}{l}\text { The principal ensures the availability of } \\
\text { required number of health educators }\end{array}$ & 359 & 2.43 & 1.03 & - & 387 & 2.41 & 1.17 & - \\
\hline 4. & $\begin{array}{l}\text { The principal ensures adequacy of } \\
\text { experienced health educators. }\end{array}$ & 359 & 2.37 & 0.75 & - & 387 & 2.33 & 0.87 & - \\
\hline 5 & $\begin{array}{l}\text { The principal ensures adequacy of } \\
\text { qualified health educators. }\end{array}$ & 359 & 2.31 & 1.15 & - & 387 & 2.25 & 1.09 & - \\
\hline 6 & $\begin{array}{l}\text { The principal ensures adequacy of } \\
\text { health educators of both sexes. }\end{array}$ & 359 & 2.23 & $1.03-$ & & 387 & 2.14 & 0.75 & - \\
\hline & Total & & 14.6 & 5.86 & & & 14.5 & 5.78 & \\
\hline & Grand Mean & & 2.47 & 0.97 & & & 2.42 & 0.96 & \\
\hline
\end{tabular}

Research Question 3: What is the relationship between supportive principals and health educators' retention in public secondary schools in Delta and Edo states?

Table-3. Mean Rating of Respondents on Relationship between Supportive Principals and Health educators' Retention in Public Secondary Schools in Delta and Edo states.

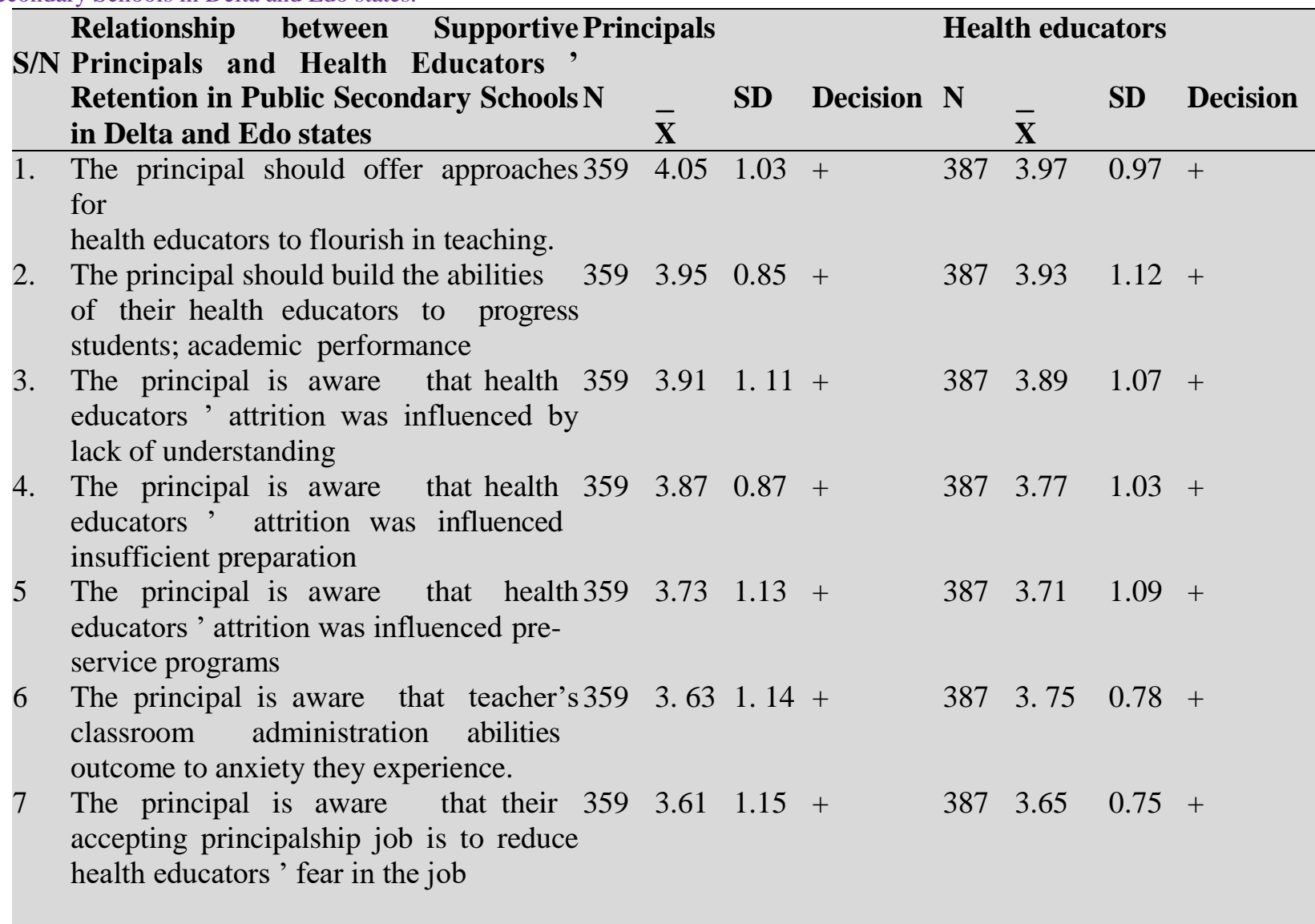

Studies

Volume 4, Issue 2, pp. 35-46

2021

DOI: $10.53935 / 2641-533 x . v 4 i 2.154$

Funding: This study received no specific

financial support.

Article History:

Received: 2 August 2021

Revised: 6 September 202

Accepted: 27 October 2021

Published: 25 November 2021

(C) 2021 by the authors; licensee Academic Publishing Group 


\begin{tabular}{|c|c|c|c|c|c|c|c|c|}
\hline \multirow{3}{*}{$\mathbf{S} / \mathbf{N}$} & \multicolumn{4}{|c|}{ Relationship between Supportive Principals } & \multicolumn{4}{|c|}{ Health educators } \\
\hline & Principals and Health Educators & 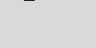 & & & & & & \\
\hline & $\begin{array}{l}\text { Retention in Public Secondary Schools N } \\
\text { in Delta and Edo states }\end{array}$ & $\overline{\mathbf{X}}$ & SD & Decision & $\mathbf{N}$ & $\overline{\mathbf{X}}$ & SD & Decision \\
\hline 8 & $\begin{array}{l}\text { The principal should involve health } 359 \\
\text { educators in decision-making to } \\
\text { enhances their job performance }\end{array}$ & 3.59 & 0.93 & + & 387 & 3.61 & 1.09 & + \\
\hline 9 & $\begin{array}{l}\text { The principal is aware that } 359 \\
\text { contemporary educational calamity is } \\
\text { hard for new health educators }\end{array}$ & 3.55 & 1.07 & + & 387 & 3.53 & 0.87 & + \\
\hline 10 & $\begin{array}{l}\text { The principal should support teacher's } 359 \\
\text { desires, particularly in the aspects that } \\
\text { openly influence them daily }\end{array}$ & 3.49 & 0.76 & + & 387 & 3.49 & 1.07 & + \\
\hline & Total & 34.2 & 3.91 & & & 37,28 & 9.84 & \\
\hline & Grand Mean & 3.42 & 0.39 & & & 3.73 & 0.98 & \\
\hline
\end{tabular}

The data in Table 2 shows that the mean rating from items 1 to 10 on the relationship between supportive principals and health educators 'retention in public secondary schools in Delta and Edo states. The respondents agreed on all the items that the principal should offer approaches for health educators to flourish in teaching, the principal should build the abilities of their health educators to progress students; academic performance, the principal is aware that health educators ' attrition was influenced by lack of understanding, the principal is aware that health educators ' attrition was influenced insufficient preparation, the principal is aware that health educators ' attrition was influenced pre-service programs, the principal is aware that teacher's classroom administration abilities outcome to anxiety they experience, the principal is aware that their accepting principalship job is to reduce health educators' fear in the job, the principal is aware that involving health educators in decision-making, enhances their job performance, the principal is aware that contemporary educational calamity is hard for new health educators and the principal should support teacher's desires, particularly in the aspects that openly influence them daily

With the data in Table 3 and the mean rating from items 1 to 10, the subsequent were noted. The mean rating for principals was 3.42 and standard deviation of 0.39 while the mean rating for health educators was 3.73 and standard deviation of 0.98 . With the level of acceptance for the study as 2.50 , the ratings of principals and health educators were higher than the criterion level of acceptance. This showed that relationship between supportive principals and health educators' retention in public secondary schools in Delta and Edo states was high as the ratings were high.

Hypothesis 1: There is no significant relationship between work load and health educators' retention in public secondary schools in Delta and Edo states.

Table-4. Pearson Product Moment Correlational Coefficient (r) Analysis on Significant Relationship between Work load and Health educators' Retention in public secondary schools in Delta and Edo States

\section{Academia}

International Journal of Educational

Studies

Volume 4, Issue 2, pp. 35-46

2021

DOI: $10.53935 / 2641-533 x . v 4 i 2.154$

Funding: This study received no specific

financial support.

Article History:

Received: 2 August 2021

Revised. 6 September 2021

Revised: 6 September 202

Accepted: 27 October 2021

(C) 2021 by the authors; licensee Academic

Publishing Group

\begin{tabular}{llllllllll}
\hline Groups & N $\begin{array}{l}\text { Summatio } \\
\mathbf{n}\end{array}$ & $\begin{array}{l}\text { Sum of } \\
\text { Square }\end{array}$ & $\mathbf{Y}$ & $\mathbf{X}$ & $\begin{array}{c}\text { Calculated } \mathbf{r} \\
\text { Value }\end{array}$ & $\begin{array}{c}\text { Critical } \\
\text { Value }\end{array}$ & Decision \\
\hline Principals & 3 & 452 & 1149 & & & & & Significant \\
& 5 & & & 2018 & 7 & 0.54 & 0.19 & Reject Ho $^{1}$ \\
Health & 3 & 508 & 1718 & & 4 & & & \\
Educators & 8 & & & & & & & \\
\hline Significant at 0.05 level & & &
\end{tabular}

Data in Table 4 shows Pearson Product Moment Correlational Coefficient (r) Analysis of the relationship between work load and health educators' retention in public secondary schools in Delta and Edo States. The calculated $r$ value of 0.54 was greater than the critical $r$ value of 0.19 .. Thus, the null hypothesis which states that there is no significant relationship between work load and health educators' retention in public secondary schools in Delta and Edo States was rejected. 
Hypothesis 2: There is no significant relationship between class sise and health educators' retention in public secondary schools in Delta and Edo states.

Table-5. Pearson Product Moment Correlational Coefficient (r) Analysis on the Significant Relationship between Class size and Health educators ' Retention in public Secondary Schools in Delta and Edo States

\begin{tabular}{lllllllll}
\hline Groups & $\mathbf{N}$ & $\begin{array}{l}\text { Summatio } \\
\mathbf{n}\end{array}$ & $\begin{array}{l}\text { Sum of } \\
\text { Square }\end{array}$ & $\mathbf{Y}$ & Df & $\begin{array}{c}\text { Calculated r } \\
\text { Value }\end{array}$ & $\begin{array}{c}\text { Critical } \\
\text { Value }\end{array}$ & Decision \\
\hline $\begin{array}{l}\text { Principals } \\
\begin{array}{l}\text { Health } \\
\text { educators }\end{array}\end{array}$ & 35 & 452 & 1742 & & & & & \\
\hline $\begin{array}{l}\text { Significant at } 0.05 \text { level } \\
\text { V }\end{array}$ & & 2011 & $\mathbf{2 0 0 2}$ & 7 & 1.14 & 0.19 & Significant $_{\text {Reject } \mathrm{Ho}_{2}}$ \\
\hline
\end{tabular}

Data in Table 5 shows Pearson Product Moment Correlational Coefficient (r) Analysis of relationship between class size and health educators' retention in public secondary schools in Delta and Edo States. The calculated $r$ value of 1.14 was greater than the critical $r$ value of 0.19 .. Thus, the null hypothesis which states that there is no significant relationship between class size and health educators ' retention in public secondary schools in Delta and Edo States was rejected.

Hypothesis 3. There is no significant relationship between supportive principals and health educators retention in public secondary schools in Delta and Edo states .

Table-6. Pearson Product Moment Correlational Coefficient (r) Analysis on Significant Relationship between Supportive principals and Health educators' Retention in Public Secondary Schools in Delta and Edo States.

\begin{tabular}{|c|c|c|c|c|c|c|c|c|}
\hline Groups & $\mathbf{N}$ & $\begin{array}{l}\text { Summatio } \\
\text { n }\end{array}$ & $\begin{array}{l}\text { Sum of } \\
\text { Square }\end{array}$ & $\begin{array}{l}\square X \\
Y\end{array}$ & Df & $\begin{array}{c}\text { Calculated } \mathbf{r} \\
\text { Value }\end{array}$ & $\begin{array}{c}\text { Critical } \mathbf{r} \\
\text { Value }\end{array}$ & Decision \\
\hline Principals & 35 & 420 & 1004 & & & & & Significant \\
\hline $\begin{array}{l}\text { Health } \\
\text { educators }\end{array}$ & 38 & 380 & 1102 & 1132 & $\begin{array}{l}7 \\
4 \\
\end{array}$ & 1.13 & 0.19 & Reject $\mathrm{Ho}_{2}$ \\
\hline
\end{tabular}

Data in Table 6 shows Pearson Product Moment Correlational Coefficient (r) Analysis of relationship between supportive principals and health educators ' retention in public secondary schools in Delta and Edo States. The calculated $r$ value of 1.13 was greater than the critical $r$ value of 0.19 .. Thus, the null hypothesis which states that there is no significant relationship between supportive principals and health educators retention in public secondary schools in Delta and Edo States was rejected.

\section{Findings}

1 Work load, class size relate with health educators' retention negatively in public secondary schools in Delta and Edo States..

2 Supportive principals relate with health educators' retention positively in public secondary schools in Delta and Edo States .

4 There was a significant relationship among work load, class size supportive principals and health educators' retention in public secondary schools in Delta and Edo States.

\section{Conclusion}

1 Work load negatively relates with health educators' retention in public secondary schools in Delta and Edo States was low as the ratings were low.

2 Class sise negatively relates with health educators' retention in public secondary schools in Delta and Edo States was low as the ratings were low.

International Journal of Educational Studies

Volume 4, Issue 2, pp. 35-46

2021

DOI: $10.53935 / 2641-533 x . v 4 i 2.154$ Funding: This study received no specific financial support.

Article History:

Received: 2 August 2021

Revised. 6 September 2021

Revised: 6 September 202

Accepted: 27 October 2021

(D) 2021 by the authors; 2021

Publishing Group upportive principals negatively relate with health educators' retention in public secondary schools in Delta and Edo States was high as the ratings were high.

4 Work load, class size, supportive principals significantly relate with health educators' retention in public secondary schools in Delta and Edo States.

1. What is the relationship between work load and retention in public secondary schools in Delta and Edo states?

2. What is the relationship between class sise and retention in public secondary schools in Delta and Edo states? 
3. What is the relationship between supportive principals and retention in public secondary schools in Delta and Edo states?

Recommendations Based on the findings, the subsequent recommendations were made:

Delta and Edo states governments should perform an investigation to fill areas of insufficiency, rationalise allotment of health educators and guarantee there is equilibrium in deployment.

\section{References}

Anhorn, R. (2008). The profession that eats its young. The Delta Kappa Gamma Bulletin, 74(3), 15-26.

Bennell, P. (2004). Teacher motivation and incentives in sub-Saharan Africa and Asia. Knowledge and Skills for development, Brighton.

Certo, J. L., \& Fox, J. E. (2002). Retaining quality teachers. The High School Journal, 86(1), 57-75.

Coleman, J. S. (1966). Equality of educational opportunity. Education economics -wikipedia, the free encyclopedia.

Craig, C. J. (2014). From stories of staying to stories of leaving: A US beginning teacher's experience. Journal of Curriculum Studies, $46(1), 81-115$.

Demerouti, E., Bakker, A. B., Nachreiner, F., \& Schaufeli, W. B. (2001). The job demands-resources model of burnout. Journal of Applied Psychology, 86(3), 499-512.

Dyer, L., \& Reeves, T. (1995). Human resource strategies and firm performance: What do we know and where do we need to go? International Journal of Human Resource Management, 6(3), 656-670.

Eisenberger, R., Huntington, R., Hutchison, S., \& Sowa, D. (1986). Perceived organizational support. Journal of Applied Psychology, 71(3), 500-507.

Enogholase, G. (2013). Edo peoples democratic party (PDP) challenges government to declare debt profile. Vanguard Newspaper Tuesday December, 31, 13-15.

Federal Republic of Nigeria. (2014). National policy on education (pp. 39-40 ). Nigeria Lagos NERDC Press.

Gardner, R. D. (2010). Should I stay or should I go? Factors that influence the retention, turnover, and attrition of K-12 music teachers in the United States. Arts Education Policy Review, 111(3), 112-121.

Gonzalez, L. E., Brown, M. S., \& Slate, J. R. (2008). Health educators who left the teaching profession: A qualitative understanding. Qualitative Report, 13(1), 1-11.

Greenlee, B., \& Brown, J. J. (2009). Retaining health educators in challenging schools. Education, 130(1), 96- 109.

Hawkins, W., D. (2018). Predictors of affective organizational commitment among high school principals. Virginia, Blacksburg.

Henry, G. T., Bastian, K. C., \& Fortner, C. K. (2011). Stayers and leavers: Early-career teacher effectiveness and attrition. Educational Researcher, 40(6), 271-280.

Higton, J., Leonardi, S., Choudhoury, A., Richards, N., Owen, D., \& Sofroniou, N. (2017). Teacher workload survey 2016.

Hughes, G. D. (2012). Teacher retention: Teacher characteristics, school characteristics, organizational characteristics, and teacher efficacy. The Journal of Educational Research, 105(4), 245-255.

Ibadin, V. O. (2010). An analysis of teacher's utilization in urban and rural secondary schools in the Mid-Western States of Nigeria. European Journal of Education Studies, 2(2).

Jerome, N. (2013). Application of the Maslow's hierarchy of need theory; impacts and implications on organizational culture, human resource and employee's performance. International Journal of Business and Management Invention, 2(3), 39-45.

Johnson, S. M., \& Birkeland, S. E. (2003). Pursuing a "sense of success": New teachers explain their career decisions. American Educational Research Journal, 40(3), 581-617.

Kersaint, G., Lewis, J., Potter, R., \& Meisels, G. (2007). Why health educators leave: Factors that influence retention and resignation. Teaching and Teacher Education, 23(6), 775-794. Available at: https://doi.org/10.1016/j.tate.2005.12.004.

Margolis, J. (2008). What will keep today's teachers teaching? Looking for a hook as a new career cycle emerges. Teachers College Record, 110(1), 160-194.

Mathieu, J. E., \& Zajac, D. M. (1990). A review and meta-analysis of the antecedents, correlates, and consequences of organizational commitment. Psychological Bulletin, 108(5), 171-194.

Mee, M., \& Haverback, H. R. (2014). Commitment, preparation, and early career frustrations: Examining future attrition of middle school health educators. American Secondary Education, 42(3), 39-51.

Moritz, G. (2011). The relationship between proactive personality, affective commitment and the role of job stressors. Twente Morrow, P.C: Portal University.

Ng, J. C., \& Peter, L. (2010). Should I stay or should I go? Examining the career choices of alternatively licensed teachers in urban schools. The Urban Review, 42(2), 123-142.

International Journal of Educational Studies

Volume 4, Issue 2, pp. 35-46

2021

DOI: $10.53935 / 2641-533 x . v 4 i 2.154$

Funding: This study received no specific

financial support.

Article History:

Received: 2 August 2021

Revised: 6 September 2021

Revised: 6 September 2021

Accepted: 27 October 2021

Published: 25 November 2021 by the authors; licensee Academic

Publishing Group
Ogboro, I., \& Adeyemi, J. K. (2017). The levels of deployment, utilization and job performance of health educators in the public senior secondary schools in Edo state. International Journal of Education, Learning and Development, 5(2), 21-34.

Pekins, B. K. (2016). Where we learn: The cube survey of Urnam school climate taken from.

Perrachione, B. A., Rosser, V. J., \& Petersen, G. J. (2008). Why do they stay? Elementary health educators ' perceptions of job satisfaction and retention. Professional Educator, 32(2), 1.

Petty, T. M., Fitchett, P., \& O'Connor, K. (2012). Attracting and keeping health educators in high-need schools. American Secondary Education, 40(2), 67-88.

Rhoades, L., \& Eisenberger, R. (2002). Perceived organizational support: A review of the literature. Journal of Applied Psychology, 87(4), 698-714. 
Sass, D. A., Seal, A. K., \& Martin, N. K. (2010). Predicting teacher retention using stress and support variables. Journal of Educational Administration, 49(2), 200-215.

Sellen, P. (2016). Teacher workload and professional development in England's secondary schools: Insights from TALIS: Education Policy Institute.

Sergiovanni, T. J., McCarthy, M. M., \& Kelleher, P. (2004). Educational governance and administration (5th ed.). USA: Pearson Educationalist Inc.

Smithers, A., \& Robinson, P. (2000). Coping with teacher shortages: Centre for Education and Employment Research.

Spector, P. E. (2016). Industrial and organisational psychology: Research and practice. Australia: John Wiley and Sons.

Supovitz, J., Sirinides, P., \& May, H. (2010). How principals and peers influence teaching and learning. Educational Administration Quarterly, 46(1), 31-56.

Sutcher, L., Darling-Hammond, L., \& Carver-Thomas, D. (2016). A coming crisis in teaching? Teacher supply, demand, and shortages in the U.S (pp. 39-45). Palo Alto, CA: Learning Policy Institute.

Wahlstrom, K. L., \& Louis, K. S. (2008). How teachers experience principal leadership: The roles of professional community, trust, efficacy, and shared responsibility. Educational Administration Quarterly, 44(4), 458-495.

World Bank: Global Education Centre. (2005). Recruiting, retaining and retraining secondary school health educators and principals in Sub-Saharan Africa (pp. 9-20): Global Education Centre, Academic for Educational Development.

\author{
International Journal of Educational \\ Studies \\ Volume 4, Issue 2, pp. 35-46 \\ 2021 \\ DOI: $10.53935 / 2641-533 x . v 4 i 2.154$ \\ Funding: This study received no specific \\ financial support. \\ Article History: \\ Received: 2 August 2021 \\ Revised: 6 September 2021 \\ Accepted: 27 October 2021 \\ (C) 2021 by the authors; licensee Academic \\ Publishing Group
}

